\title{
ANALISIS SALURAN PEMASARAN BAHAN OLAHAN KARET (BOKAR) DI KECAMATAN MANDOR KABUPATEN LANDAK
}

\author{
SISWANDI ${ }^{1)}$, ERLINDA YURISINTHAE $^{2)}$, NOVIRA KUSRINI ${ }^{2)}$ \\ 1) Alumni Magister Manajemen Agribisnis Fakultas Pertanian Universitas \\ Tanjungpura Pontianak. \\ 2) Staf Pengajar Fakultas Pertanian Universitas Tanjungpura Pontianak
}

\begin{abstract}
This study aimed to analyze the marketing channels on the traditional's marketing channel through intermediary traders and to analyze the marketing channel through farmer's are reviewed from a marketing margin spread, farmer share, and to find out which channels more efficient in Mandor District, Landak Regency.

This research shows that the marketing margin in channel II is fewer than channel I and the farmer's share in channel II is larger than channel I. So this research conclude that the marketing channels II (via farmer's group) is more efficient compared to the channel I (through intermediary traders) in the Mandor District of Landak regency.

On the marketing channel I, the marketing process is still efficient but the farmers receive less price share than in channel II. On the marketting channel II become priority because its more efficient, the farmers receive more profit.
\end{abstract}

Keywords: Marketing rubber, margin, efficiency

\section{PENDAHULUAN}

Indikator keberhasilan sub-sektor perkebunan saat ini termasuk komoditas karet, barometernya diukur dengan dimensi yang lebih luas, bukan hanya peningkatan produksi dan devisa bagi negara, namun esensi lainnya adalah peningkatan pendapatan dan kesejahteraan para pelaku dalam sistem komoditas ini, terutama bagi petani selaku produsen karet.Refleksi dari sistem usaha tani (on farm) maupun dari sistem pemasaran yang baik akan tercermin pada tingkat pendapatan dan kesejahteraan petani. Dalam upaya peningkatan pendapatan dan kesejahteraan petani pada perkebunan karet rakyat di kabupaten Landak, masalah utama yang dihadapi petani yaitu pada sub-sistem pemasaran.

Sistem pemasaran bahan olah karet (BOKAR) di Kabupaten Landak saat ini terdapat dua saluran pemasaran, pertama melalui saluran pemasaran tradisional oleh pedagang perantarayaitu (pedagang perantara desa dan pedagang perantara kecamatan),saluran pemasaran kedua melalui lembaga kelompok tani yang memasarkan karet petani langsung ke pabrik crumbrubber.

Pada sistem pemasaran BOKAR melalui saluran tradisional, karet dijual keindustri crumbrubber melalui pedagang perantara sehingga sistem pemasaran seperti ini kurang menguntungkan atau kurang berpihak pada petani sebagai produsen BOKAR dengan demikian para pelaku pemasaran dan industri lebih menikmati keuntungan yang lebih besar dibandingkan dengan petani selaku produsen. 
Pada sistem pemasaran karet melaluisaluran lembaga kelompok tani yang telah melakukan pemasaran langsung ke pabrik crumbrubber adalah gabungan kelompok tani Liansipi kecamatan Mandor kabupaten Landak.Pada pemasaran melalui saluran lembaga kelompok ini dapat memperkecil marjin pemasaran terutama dari biaya transportasi, meningkatkan posisi tawar petani, dapat meningkatkan atau menyeragamkan mutu karet, sehingga secara garis besar pemasaran secara berkelompok dapat meningkatkan nilai jual karet dan lebih menguntungkan bagi petani,dengan kata lain dapat lebih efisien.

Sehubungan hal tersebut dalam penelitian ini yang penting untuk diketahui adalah : Apakah sistem pemasaran bahan olah karet (BOKAR) melalui saluran pemasaran lembaga kelompok tani lebih efisien apabila dibandingkan dengan saluran pemasaran tradisional oleh pedagang perantara dan untuk mengetahui seberapa besar tingkat efisiensi sistem pemasaran bahan olah karet rakyat (BOKAR) pada saluran pemasaran tradisional oleh pedagang perantara dan saluran pemasaran oleh lembaga kelompok tani di kecamatan Mandor kabupaten Landak.

\section{METODE PENELITIAN}

Metode yang akan dilakukan dalam penelitian adalah metode survey, lokasi penelitian dilaksanakan di desa Mandor, kecamatan Mandor, kabupaten Landak. Pemilihan lokasi penelitian dilakukan secara purposive sampling dengan pertimbangan bahwa kecamatan Mandor merupakan sentra produksi karet di kabupaten Landak, dan terdapat satu-satunya GAPOKTAN perkebunan karet yang telah melakukan pemasaran karet langsung ke pabrik Crumbrubber.

Populasi dalam penelitian ini adalah anggota GAPOKTAN Liansipi yang beranggotakan 94 petani, yang tergabung dalam 4 kelompok tani, 3 pedagang desa dan 1 pedagang kecamatandihitung dengan menggunakan rumus Slovin dengan presisi $16 \%$, sebagai berikut:

$$
n=\frac{N}{1+N(e)^{2}}
$$

Di mana:

$$
\begin{array}{lll}
\mathrm{n} & = & \text { jumlah sampel } \\
\mathrm{N} & = & \text { jumlah populasi } \\
\mathrm{e} & = &
\end{array}
$$

persenkelonggaranketidaktelitiankarenakesalahanpengambilansampel yang masihdapatditolerirataudiinginkan

Berdasarkan rumus tersebut, maka jumlah sampel yang diperoleh adalah:

$$
\mathrm{n}=\frac{94}{1+94(0,16)^{2}}=27,59=28 \text { responden }
$$

$$
\mathrm{Ni}=\mathrm{Ni} / \mathrm{N} \times \mathbf{n}
$$

Sampelsebanyak 28 petani karet selanjutnya dialokasikan sebagai berikut:

$\begin{array}{ll}\text { Petani Swadaya Mandiri } & =16 / 94 \times 28=4,77=5 \\ \text { Petani Maju Sejahtera } & =25 / 94 \times 28=7,45=7 \\ \text { Petani Maju Bersama } & =22 / 94 \times 28=6,55=7 \\ \text { Petani Sejahtera Bersama } & =31 / 94 \times 28=9,23=9\end{array}$

Di sampingitu yang termasuk populasi adalah pedagang desa, pedagang kecamatan termasuk jumlah atau volume penjualannya, tentunya hanya yang ada hubungannya dengan proses penelitian ini. 
Sampelpemasarankaretdalampenelitianadalahpemasaran

karetsheet, sedangkanpemasaran karet lump tidak dimasukkan pada penelitian ini walaupun pada kenyataannya karet lump dijual petani dan dibeli oleh pedagang, namun untuk lembaga pemasaran saluran II hanya membeli karet dalam bentuk sheet.

Data primer diperolehlangsungdaripara responden yaitu petani, pengurus/ketua kelompok tani, gabungan kelompok tani, pedagang pengumpul, pedagang desa dan pedagang perantara tingkat kecamatan.Data sekunder diperoleh dari Dinas Perkebunan dan Kehutanan Kabupaten Landak, Dinas Perindustrian dan Perdagangan Kabupaten Landak, Dinas Perkebunan Provinsi Kalimantan Barat, Kantor Statistik, Kantor Desa, industri crumbrubber, Gabkindo, juga melalui situs-situs di internet.

Dalampenelitianini yang akan dibandingkan adalah antara marjin pemasaran pada saluran pasar tradisional dengan marjin pemasaran pada saluran yang melalui kelompok tani. Sesuai Rumus Marjin Pemasaran = Harga Jual - Harga Beli, Rumus Marjin Keuntungan $=$ Harga Jual - Harga Pokok Produksi (HPP), HPP = Biaya Total Produksi.

Variabel penelitiannya meliputi :

1. Penerimaan petani yang pemasarannya ke pabrik/industri crumbrubber secara berkelompok adalah jumlah uang yang diterima petani sesudah di kurangi marjin pemasaran.

Penerimaan petani yang pemasarannya kepada pedagang perantara secara perorangan adalah jumlah uang yang diterima petani, yaitu jumlah produksi karet petani $(\mathrm{Kg})$ dikalikan dengan harga karet yang berlaku pada pedagang perantara di pedesaan.

2. Marjin Pemasaran pada saluran pemasaran melalui kelompok tani adalah total biaya yang dikeluarkan oleh petani sebagai biaya di dalam pelaksanaan pemasaran antara lain meliputi biaya upah tenaga timbang, bongkar muat dan sortasi, biaya penyusutan berat karet selama dalam perjalanan menuju pabrik, biaya transportasi karet ke pabrik/industri crumbrubber, biaya iuran kelompok yang pemanfaatannya untuk honor pengurus kelompok, uang jalan pelaksana pemasaran ke pabrik, alat tulis dan alat timbang, dana sosial.Marjin pemasaran pada lembaga tradisional adalah biaya pemasaran pada pedagang perantara termasuk keuntungan yang diperoleh pedagang perantara tingkat desa maupun tingkat kecamatan.

3. Harga karet di tingkat prosesor.Adalah sejumlah uang yang dibayarkan oleh prosesor/industri crumbrubber atas harga karet yang dibawa oleh kelompok tani maupun oleh pedagang perantara tingkat kecamatan.

Untuk menguji hipotesis yang diduga besarnya marjin pada sistem pemasaran tradisional melalui pedagang perantara lebih besar jika dibandingkan dengan besarnya marjin pemasaran melalui kelompok tani,caranya dengan menghitung selisih marjin antara saluran pemasaran tradisional yang melalui pedagang perantara dengan marjin pada saluranpemasaran yang melaluikelompoktani.

Untukmelihattingkatefisiensi saluran pemasaran maka perhitungan dengan rumus besarnya marjin pemasaran sebagai berikut :

Keterangan :

$$
\mathrm{M}_{\mathrm{l} 1}=\mathrm{P}_{\mathrm{s}}-\mathrm{P}_{\mathrm{b}} \text { atau } \mathrm{M}_{\mathrm{l}}=\mathrm{b}_{\mathrm{t}}-\mathrm{k}_{\mathrm{i}}
$$

$\mathrm{Mji}=$ marjin pada lembaga pemasaran pada tingkat ke- $\mathrm{i}$

Psi $=$ harga penjualan lembaga pemasaran pada tingkat ke-i

$\mathrm{Pbi}=$ harga pembelian lembaga pemasaran pada tingkat ke-i

$\mathrm{Bti}=$ biaya lembaga pemasaran pada tingkat ke-i

$\mathrm{Ki}=$ keuntungan pada lembaga pemasaran tingkat ke-i

Di mana : persentase marjin pemasaran yang paling rendah adalah marjin pemasaran yang paling efisien.

ApabilamarjindinyatakandalambentukpersentasemakadapatdisebutsebagaiMarkup. 


$$
\text { Mark }- \text { up }=\frac{\text { Marjin pemasaran }}{\text { Harga penjualan }} \times 100 \%
$$

Untukmenentukanbesarnyabagianharga yang diterimaolehpetani, makarumus yang digunakanadalah :

$$
\mathrm{FS}=\frac{\mathrm{H}_{1}}{\mathrm{H}_{\mathrm{o}}} \times 100 \%
$$

Keterangan $\quad: \mathrm{Hj}=$ Harga jual ditingkat petani

$$
\text { Ho = Hargajualditingkatkonsumen }
$$

Keterangan : Persentase famer's share yang lebihtinggiadalahfarmer's share yang lebihefisien

Dari hasilanalisisantarafarmer's share dan marjin maka akan dapat dibandingkan dimana suatu pemasaran akan lebih efisien bila :

- Persen (\%) FS > Persen (\%) marjin maka saluran pemasaran dapat dikatakan efisien.

- Persen (\%) FS = Persen (\%) marjin maka saluran pemasran impas, dapat dikatakan efisien.

- Persen (\%) FS < Persen (\%) marjin, maka dapat dikatakan tidak efisien.

Persentase marjin didapatkan berdasarkan hasil perhitungan Mark-up.

Besarnyakeuntungandarisemua lembaga pemasaran yang terlibat dicari dengan indeks keuntungan digunakan rumus berikut :

Keterangan :

$$
P=\frac{K_{l}}{B_{i}} d \quad K_{i}=H_{j}-H_{b}-B_{l}
$$

PI = Profitability Index

$\mathrm{K}_{\mathrm{i}} \quad=$ Keuntungan lembaga pemasaran $(\mathrm{I}=1,2, \ldots . . \mathrm{m} ; \mathrm{m}=$ jumlah lembaga yang terlibat)

$\mathrm{B}_{\mathrm{i}} \quad=$ Biaya lembaga pemasaran $(\mathrm{I}=1,2, \ldots \ldots \mathrm{z} ; \mathrm{z}=$ jumlah jenis biaya $)$

$\mathrm{P}_{\mathrm{ji}} \quad=$ Harga jual I

$\mathrm{P}_{\mathrm{bi}} \quad=$ Harga beli lembaga ke I

$\mathrm{B}_{\mathrm{ij}} \quad=$ Biaya lembaga pemasaran ke I dari berbagai jenis

Dari hasil analisis profitability index akan diketahui, jika nilai PI semakin besar maka semakin efisien.

\section{HASIL DAN PEMBAHASAN}

\section{Lembaga dan Fungsi Pemasaran Karet Sheet}

a. Saluran Pemasaran I

Saluran pemasaran I merupakan saluran pemasaran yang terdiri dari petani, pedagang desa, pedagang kecamatan, dan crumbrubber (PT New Kalbar Processor). Saluran pemasaran ini digunakan oleh 8 orang petani $(7,84 \%)$ dari total petani responden, 3 pedagang desa, dan 1 pedagang kecamatan.

Fungsi-fungsi yang dilakukan oleh lembaga pemasaran adalah sebagai berikut :

1. Kegiatan Pedagang Pengumpul Tingkat Desa

Dalam kegiatan pembeliannya pedagang pengumpul tingkat desa menerima karet sheet dalam kondisi seperti kadar air yang masih tinggi, tingkat kebersihan yang tidak menentu dan sebagian ada yang lebih kering dan bersih. Sedangkan frekuensi penjualan yang mereka lakukan biasanya 4 sampai 6 kali setiap bulannya. Volume karet sheet yang mereka jual dalam setiap kali pengangkutan biasanya $75 \mathrm{~kg}$ karet sheet.

Pedagang pengumpul tingkat desa melakukan fungsi pertukaran adalah penjualan dan pembelian, fungsi fisik adalah pengangkutan dan kegiatan bongkar 
muat dan fungsi pelancar adalah pembiayaan dan kredit. Biaya-biaya yang diperhitungkan pedagang pengumpul tingkat desa diantaranya biaya pengeringan sebesar $\mathrm{Rp} 100,00$ per $\mathrm{kg}$ atau $1,72 \%$ dari biaya pemasaran, biaya penyusutan sebesar Rp 50,00 per $\mathrm{kg}$ atau $0,86 \%$ dari biaya pemasaran, biaya bongkar muat sebesar Rp100,00 per $\mathrm{kg}$ atau 1,72\% dari biaya pemasaran, biaya transportasi $\mathrm{Rp}$ 333,00 per $\mathrm{kg}$ atau $5,74 \%$ dari biaya pemasaran.

2. Kegiatan Pedagang Pengumpul Tingkat Kecamatan

Pedagang pengumpul tingkat kecamatan melakukan fungsi pertukaran yaitu penjualan dan pembelian dan fungsi fisik yaitu kegiatan pengangkutan dan bongkar muat.

Biaya-biaya yang diperhitungkan pedagang pengumpul tingkat kecamatan diantaranya biaya pengeringansebesar $\mathrm{Rp} 100,00$ per $\mathrm{kg}$ atau $1,23 \%$ dari biaya pemasaran, biaya sebesar $\mathrm{Rp} \mathrm{50,00} \mathrm{per} \mathrm{kg}$ atau $0,61 \%$ dari biaya pemasaran, biaya bongkar muat sebesar Rp100,00 per $\mathrm{kg}$ atau 1,23\% dari biaya pemasaran, biaya transportasi $\mathrm{Rp} 250,00$ per $\mathrm{kg}$ atau 3,08\% dari biaya pemasaran.

\section{b. Saluran Pemasaran II}

Saluran pemasaran II merupakan saluran pemasaran yang terdiri dari petani, kelompok tani dan crumbrubber (PT New Kalbar Processor). Pengurus kelompok tani melakukan sortir dulu untuk menjaga kemungkinan masih ada karet yang terkontaminasi dan memisahkan antara sheet dan lumb, menimbang karet, memuat karet ke dalam kendaraan untuk dibawa ke tempat pabrik/prosesor. Setelah selesai pemasaran ke pabrik, pengurus kelompok tani menghitung biaya pemasaran, kemudian membagikan uang hasil penjualan BOKAR kepada masing-masing petani setelah dikurang biaya pemasaran.

Kelompok tani melakukan fungsi fisik yaitu kegiatan pengangkutan dan bongkar muat.Pemasaran karet sheet melalui kelompok tani ini akan timbul marjin pemasaran antara lain : upah karyawan sortir, timbang, bongkar muat, dan biaya transportasi dari kelompok tani ke tempat prosesor, penyusutan berat timbangan karet, serta iuran dan dana sosial kelompok.

\section{Analisis Marjin Pemasaran}

Analisis marjin pemasaran karet sheetdalam penelitian akan dibedakan berdasarkan saluran pemasaran yang ada di daerah penelitian, besarnya marjin pada tiaptiap saluran pemasaran adalah :

a. Saluran I (pertama) adalah Rp 3.850,00 (47,53\%) per kg karet sheet yang terdiri dari biaya pemasaran sebesar Rp 1.083 (13,37\%) dengan marjin keuntungan Rp 2.767 $(34,16 \%)$ per kg karet sheet, pada saluran I ini marjin lebih tinggi karena adanya pihak pedagang pengumpul.

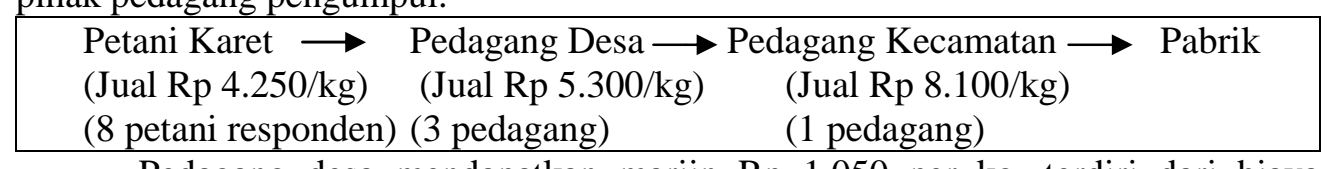

Pedagang desa mendapatkan marjin $\mathrm{Rp} 1.050$ per $\mathrm{kg}$, terdiri dari biaya pengeringan Rp 100 per kg,biaya penyusutan Rp 50 per kg, biaya bongkar/muat Rp 100 per kg, biaya transportasi Rp 333 per kg, keuntungan Rp 467 per kg. Pedagang kecamatan mendapat marjin Rp 2.800 per $\mathrm{kg}$, terdiri dari biaya pengeringan $\mathrm{Rp} 100$ per $\mathrm{kg}$, biaya penyusutan Rp 50 per $\mathrm{kg}$, biaya bongkar/muat $\mathrm{Rp} 100$ per $\mathrm{kg}$, biaya transportasi Rp 250 per $\mathrm{kg}$, keuntungan Rp 2.300 per $\mathrm{kg}$. Jadi total marjin pemasaran yang diterima pedagang perantara adalah sebesar $\mathrm{Rp} 3.850$ per $\mathrm{kg}$.

b. Saluran ke II (kedua) adalah Rp 1.860,00 (22,96\%)per kg karet sheet yang terdiri dari biaya pemasaran sebesar Rp 500,00 (6,17\%) dengan marjin keuntungan Rp $1.360,00(16,79 \%)$ per kg karet sheet. 


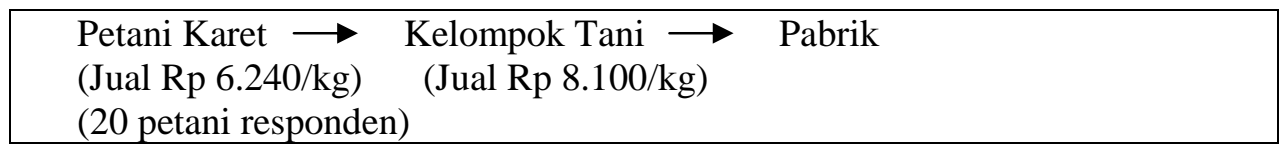

Kelompok tani mengeluarkan biaya pengeringan $\mathrm{Rp} 100$ per $\mathrm{kg}$, biaya penyusutan $\mathrm{Rp} 50$ per $\mathrm{kg}$, biaya bongkar/muat $\mathrm{Rp} 100$ per $\mathrm{kg}$, biaya transportasi $\mathrm{Rp}$ 250 per kg, keuntungan Rp 1.360 per kg. Kelompok tani mendapat marjin sebesar $\mathrm{Rp} 1.860$ per kg.

Jika petani menjual karet sheetnya pada saluran pertama, maka perbedaan harga jual petani $47,53 \%$ lebih rendah dari harga pasar

\section{Analisis F armer's Share}

Untuk mengetahui tingkat efisiensi saluran pemasaran karet sheet dari petani ke pedagang pengumpul tingkat kecamatan dapat dilihat bahwa total marjin pada saluran pemasaran yang pertama adalah $\mathrm{Rp} 3.850,00$ atau 47,53\% dari harga yang berlaku dan marjin total pada saluran kedua memiliki total marjin Rp 1.860 atau 22,96 \% sehingga dapat dilihat marjin yang terkecil yaitu pada saluran kedua.

Saluran pertama mempunyai farmer's sharesebesar $52,47 \%$ dan pada saluran kedua yaitu $77,04 \%$. Dari kedua saluran tersebut dapat dinyatakan efisien namun yang paling efisien dari kedua saluran tersebut adalah saluran II karena memiliki farmer's share lebih tinggi dari pada farmer's share saluran I, karena memiliki marjin pemasaran lebih rendah yaitu Rp 1.860,00 dengan farmer's share yang paling tinggi yaitu 77,03\%.

Dari kedua saluran pemasaran tersebut terdapat selisih nilai farmer's share $24,56 \%$ dari harga yang berlaku, berarti petani menerima harga karet sheet sama dengan harga di perusahaan atau pabrik pengolahan karet.

\section{Tingkat Keuntungan Masing-masing Lembaga Pemasaran}

Keuntungan pedagang tingkat desa $\mathrm{Rp} 467,00$ atau $8,81 \%$ per $\mathrm{Kg}$, pedagang tingkat kecamatan Rp 2.300,00 atau 28,39\% per kg.Sedangkan untuk saluran pemasaran II Rp 1.360 per kg.

\section{Analisis Profitability Index}

Profitability index pada saluran I sebesar 2,55,sedangkan profitability index pada saluran pemasaran II yaitu 2,72 yang artinya yang artinya bilamana biaya pemasaran sebesar Rp 1,00 maka keuntungan pemasaran sebesar Rp 2,72,-.

\section{KESIMPULAN DAN SARAN \\ Kesimpulan}

Marjin pada pemasaran saluran I (Rp.3.850/kg) lebih besar dibandingkan dengan saluran II (Rp.1.850/kg) yang artinya berdasarkan tinjauan marjin pemasaran maka saluran II lebih menguntungkan bagi petani.

Nilai farmer's share saluran I52,47\% lebih rendah di bandingkan dengan saluran II 77,04\%, yang artinya ditinjau dari hasil kajian farmes's share maka saluran II lebih menguntungkan bagi petani.

Nilai profitability index saluran II2,72\%, nilai ini lebih besar dibandingkan saluran I 2,55\%, yang artinya ditinjau dari hasil kajian profitability Indexmaka pada saluran II juga lebih menguntungkan bagi lembaga pemasaran dalam hal ini bagi kelompok tani.

Keuntungan yang di peroleh pada kelompok tani sebagian besar di peruntukkan bagi seluruh anggota petani seperti untuk dana sosial anggota kelompok, dana talangan anggota kelompok, untuk pembelian alat - alat yang diperlukan dalam pelaksanaan pemasaran kelompok, dan lain - lain.

Sehingga dapat di tarik kesimpulan bahwa sistem pemasaran karet sheet saluran II (melalui kelompok tani) di kecamatan Mandor kabupaten Landak lebih efisien dibandingkan dengan saluran I (melalui pedagang perantara), dan lebih menguntungkan bagi petani sebagai produsen. 


\section{Saran}

Berdasarkan uraian dari hasil penelitian di atas yang menyimpulkan bahwa saluran pemasaran II melalui kelompok tani dapat menjadi alternatif pilihan yang utama.

Pada kondisi yang belum memungkinkan petani melakukan pemasaran melalui saluran pemasaran II (melalui kelompok tani), maka saluran I (pedagang perantara) keberadaannya masih diperlukan.

Dalam upaya mengembangkan pemasaran melalui saluran II, hal yang perlu menjadi perhatian pemerintah antara lain perlu pembinaan teknis budidaya karet untuk meningkatkan produktifitas,penguatan lembaga kelompok, peningkatan kapasitas pengurus kelompok tani,fasilitasi kelompok tani untuk mendapatkan kredit investasi permodalan.

\section{DAFTAR PUSTAKA}

Azzaino, Zulkifi, 1981. Pengantar Tataniaga Pertanian, Departemen Ilmu Sosial Ekonomi Pertanian, Institut Pertanian Bogor.

Badan Pusat Statistik, 2013. Kecamatan Mandor Dalam Angka 2013, Kabupaten Landak, Kalimantan Barat.

Daniel, M., 2002. Pengantar Ekonomi Pertanian. Bumi aksara, Jakarta.

Davis, J.H dan R.A. Goldberg.1957. A Concept Agribussiness. Boston :Harvard University

Departemen Perindustrian dan Perdagangan, 2009. Nilai Eksport Karet Indonesia, Jakarta.

Dessler, Gary. 2003. Manajemen Sumber Daya Manusia. PT Macanan Jaya Cemerlang. Jakarta.

Dinas Perkebunan dan Kehutanan Kabupaten Landak, 2009. Perkebunan DalamAngka, Dinas Perkebunan dan Kehutanan Kabupaten Landak, Ngabang

Dinas Perkebunan, 2009. Perkebunan Dalam Angka, Pemerintah provinsi Kalimantan Barat, Pontianak.

Direktorat Jenderal Perkebunan, 2006. Pedoman Tehnis Budidaya karet ( Good Agricultural Practices ). Departemen Pertanian, Jakarta.

Direktorat Jenderal PHPP, 2009, Potensi dan perkembangan pasar eksport karet Indonesia di pasar internasional.

Griffin, Ricky W dan Pustay, Micheal W. 2005. Bisnis Internasional. PT Indeks. Jakarta

Gumbira-Sa'id E, Intan AH. 2001.Manajemen Agribisnis. Ghalia Indonesia. Jakarta.

Hanifah, A.M, Saefudin, 1986. Tataniaga Hasil Pertanian, UI Press, Jakarta.

Hansen,Don R dan Mowen, Maryanne M. 2005. Manajemen Accounting. China Translation and Printing Services . China.

Hernanto, Fadholi. 1989. Ilmu Usaha Tani, Penebar Swadaya, Jakarta.

Husnan, Suad dan Pudjiastuti, Enny. 2006. Dasar - Dasar Manajemen Keuangan. UPP STIM YKPN. Yogyakarta

Jogiyanto, 2004. Metodologi Penelitian Bisnis. BPFE- YOGYAKARTA.

Kotler, P. and Keller K.L.2007. Manajemen Pemasaran. Jilid 1. Alih bahasa :

Limbong, dkk. 1987. Pengantar Tataniaga Pertanian. Institut Pertanian Bogor.

Maulidi dkk dalam Litro, 1992. Analisis Pemasaran Jahe, IPB, Bogor.

Mubyarto, 1989. Pengantar Ekonomi Pertanian, LP3ES, Jakarta.

Nakhrowi, Nakhrowi Jalal. 2002. Penggunaan Teknik Ekonometri. PT Raja Grafindo Persada. Jakarta

Nasir, Mohamad, 2003. Metode Penelitian. Penerbit GHALIA INDONESIA.Jakarta

Niswonger. 1992.Prinsip - Prinsip Akuntansi I. Erlangga. Jakarta

North, D. C. 1990. Institutions, Institutional Change and Economics Performance.Cambridge University Press 
Pappas, James L dan Hirshey, Mark. 1993. Ekonomi Manajerial. Binarupa Aksara. Grogol

Prayitno, Hadi dan Lincolin Arsyad. 1987. Petani Desa dan Kemiskinan. BPFE. Yogyakarta.

Ramadhan, W., 2009. Analisis Marjin Pemasaran Sapi Potong di Kecamatan

Singosari Kabupaten Malang Provinsi Jawa Timur. http://www.deptan.go.id.

Stanton, J. William. 1995. Prinsip Pemasaran. Edisi Ketujuh. Erlangga. Jakarta

Sugiono, 2003. Statistik Untuk Penelitian. CV. ALFABETA. Bandung.

Supriyono. 1985. Manajemen Strategi dan Kebijaksanaan Bisnis.BPFE. Yogyakarta

Suratiyah,K. 2006. Ilmu Usaha Tani. Penerbit Penebar Swadaya. Depok 16952.

Soekartiwi, 1993. Ilmu Usaha Tani. UI-Press. Jakarta.

Sudioyono, A., 2002. Pemasaran Pertanian. Universitas Muhammadiyah, Malang.

Uphoff,Norman. 1986. Local Institutional Development an Analytical Sourcebook with Cases. 